\title{
Effect of The Macro-Environment Factors On the Relationship Between Firm Resources and Export Performance of Small and Medium Scale Manufacturing Enterprises in Nairobi City County, Kenya
}

\author{
Samson Kitonyi \\ Francis Kibera \\ James Gathungu \\ John Yabs
}

School of Business, University of Nairobi, Kenya

\begin{abstract}
Doi:10.19044/esj.2020.v16n28p173 URL:http://dx.doi.org/10.19044/esj.2020.v16n28p173
Submitted: 3 August 2020

Accepted: 9 September $2020 \quad$ Published: 31 October 2020

Copyright 2020 Kitonyi et al.

Distributed under Creative Commons CC-BY 4.0

OPEN ACCESS
\end{abstract}

\begin{abstract}
The aim of this study was to evaluate the influence of macro-environmental factors on the relationship between firm resources and the export performance of small and medium-sized manufacturing enterprises in Nairobi City County, Kenya. The study was based on cross sectional research design. A total of 265 out of 853 firms formed the study sample. Data was collected via a structured questionnaire. The response rate was 89.1 percent. Descriptive statistics and inferential analysis (step wise bivariate and multiple regression) was used to achieve the study objective. A five percent level was preferred in testing significance of the coefficients. The findings revealed that macro-environmental factors significantly moderated the relationship between firm resources and the export performance of small and medium-sized manufacturing enterprises in Nairobi City County, Kenya. For the firm to improve its export performance, the study recommends that firms have to take stock of firm specific resource endowments and respond to changes in the macro environment within which they operate. Also, exporting organizations must match firm innovativeness levels to external environmental conditions and internal capabilities and structures.
\end{abstract}

Keywords: Firm Resources, Macro-environment, Export Performance, Small and Medium Scale Manufacturing Enterprises, Nairobi City County. 


\section{Introduction}

A number of scholars assert that exporting is a flexible and costeffective means of gaining entry into new foreign markets. Exporting needs minimum obligations on resource commitment relative to other forms of foreign market entry modes such as licensing and Foreign Direct Investment (FDI). The advancement of a country's export performance has positive effect on the development of the economy altogether just as on individual organizations (Freixanet \& Churakova, 2018). Small and Medium Enterprises (SMEs) are subjected to higher foreign expertise and technology during the export cycle, which can eventually increase efficiency (Sadeghi \& Biancone, 2018). Finally, exporting can be used as a spring board by firms venturing in foreign trade through foreign direct investment (Gaur, Ma \& Ding, 2018).

This study was informed by three key elements in exporting as an entry point to internationalization. The three elements are explained using the three theories which have been considered by scholars in recent times. These theories include, Resource Based View (RBV), Porter's theory of competitive advantage and Firm Internationalization theory. SMEs operate in a manufacturing sub-sector where their success is influenced by the macroenvironment using a variety of resource combinations and organizational characteristics within the firm. Recent studies including Machuki and Aosa, (2011) and Gathungu et al., (2014) assert that, SMEs are faced with different challenges, some are internal, and others are external. These are observed in the micro, macro-environment and industry level in the operating environment. According to Yabs (2010) they need a robust strategy to keep afloat. It has been observed that, the firm's individual export performance is largely a function of how they respond to the environment.

Although attempts to interrogate theories and factors that affect or influence export performance have been made and published before, there has been limited research and case studies based on Small and Medium scale Manufacturing Enterprises (SMMEs) in Africa, most of the research was carried out in either developed countries or under varying frameworks (Okpara, 2009). This study is motivated by the need to establish how export performance is dependent on firm resources, and how the macroenvironment moderates the relationship between the two variables. The study recognises exporting as a core activity for many small and medium enterprises in the processes of internationalization in many developing nations including Kenya.

\section{Research Problem}

Manufacturing sector plays a significant role in economic growth of developed and developing countries. SMEs manufacturing sector is one of 
the key pillars of Kenya's Vision 2030. It contributes substantially to huge percentage of country's exports. Available statistics indicate that the manufacturing sector's contribution to GDP and total exports has been declining from $10.29 \%$ in 2015 to $9.9 \%$ in 2017 (UNIDO, 2018). In the same period, manufacturing exports as a share of total exports declined from $48.6 \%$ to $41.6 \%$. It would therefore be very difficult for Kenya to achieve high growth over an extended period of time because of the prevalent economic imbalances. According to Kiveu, Namusonge, and Muathe (2019) Kenya needs to increase its export competitiveness.

Fundamental theories including Resource Based View (Penrose, 1959; Grant, 1991) and Porters theory of competitive advantage (Porters, 1985) provide important insights into the multi-dimensional phenomenon on exporting. Philosophical and empirical proof demonstrates elements including research and development (Alam, et al., 2019), macroeconomic uncertainty (Jin, Peng \& Song, 2019), networks (Raul, Isabel \& Marta, 2016), as well as domestic institutional attributes (Ngo et al., 2016; Ribau, Moreira \& Raposo, 2017) in both industry and company level as crucial for explaining export performance. In order for enterprises to operationalize exporting and be able to efficiently and effectively use firm resources Gregory, Ngo and Karavdic (2019) assert that they must appreciate the existing challenges in the macro-environment.

Literature from developed economies has shown that the link between firm resource and export performance is weakened at different levels by macro-environment (Boso, et al., 2016; Jin, Peng \& Song, 2019). Despite most studies concentrating on various sectors including agri-food firms (Raul, Isabel \& Marta, 2016) or automobile (Imran, et al., 2018), few have explored the manufacturing sector. Others have explored at difference facets of firm resources and macro environment in emerging economies. For example financial capital (Boso, et al., 2016), financial and human resources (Kadochnikov \& Fedyunina, 2017), intangible resources (França \& Rua, 2018), and financial slack (Guo, et al., 2020). In addition, these studies are inconclusive on the nature of the relationship between firm resource, macro environment and export performance (Ngo, et al., 2016) especially on SMEs in developing countries including Kenya. This study was therefore conducted to fill the empirical gap on the effect of macro-environment on the relationship between firm resources and the export performance of small and medium-sized enterprises engaged in manufacturing and exporting.

\section{Study Hypothesis}

The Macro -environment does not influence the relationship between firm resources and export performance of Small and Medium Scale Manufacturing Enterprises in Nairobi City County, Kenya. 


\section{Literature Review}

It is argued that export performance of firms in emerging economies depends both on their firm-specific resource endowments and on the institutional environments within which they operate (Liu \& AtuaheneGima, 2018). It is claimed that firms will be likely to export when political instability is high, they face more informal competitors, and are able to grease the regulatory system via bribes. A study conducted by Krammer, Strange and Lashitew (2018) on export performance of emerging economy firm, hypothesized that firm export intensity will depend on access to critical resources such as skilled workforce, managerial talent and product quality. The study tested this conjectures using a dataset of 5,600 firms in the four largest emerging market economies (Brazil, Russia, China and India). The results confirm that the institutional environments affect export propensity through political instability and bribery, whilst the export intensity of firms depends on the availability of skilled workers and adherence to international quality standards. Their findings provided new insights into the export performance of emerging market firms (EMFs).

Firms accrue several benefits from innovation activities. Some studies including Xie and Li (2018) as well as Gregory, Ngo and Karavdic (2019) have shown that firm innovativeness is associated with enhanced export success, however the conditions under which firm innovativeness activities are most and least beneficial are not well understood. Boso, et al (2016) did a study to investigate how internal channel networking capability and structural factors as well as external environment factors affect the innovativeness -export performance relationship in emerging economies. Analysis of samples of exporting firms from Ghana and Bosnia and Herzegovina revealed that innovativeness is most beneficial for firms operating in competitive and dynamic export markets; those in less competitive and static markets do not benefit from their innovation activities to the same extent. Further, the results indicated that stronger networking capabilities and a more organic structure also enhance the innovativenessexport performance relationship.

Using a database of around 2000 manufacturing MNEs in France in 1999, a study by Bertrand (2011) examining the effects of offshore outsourcing on the export performance of firms revealed that offshore outsourcing increases export performance, the effects being stronger in the export markets where firms import intermediate goods. The study results also indicated that the firm size, the organization of intra-firm imports and the export experience moderate the effects of offshore outsourcing positively.

Leonidou, Palihawadana and Theodosiou (2011) did a study investigating national export-promotion programs as drivers of 
organizational resources and capabilities. Specifically, the study examined the effects on strategy, competitive advantage, and performance. The study tested a model connecting national export-promotion programs with export performance through the intervening role of export-related organizational resources and capabilities, export marketing strategy and export competitive advantage. The study revealed that the adoption of specific national exportpromotion programs positively strengthens the firm's export-related resources and capabilities, which in turn are instrumental in developing a sound export marketing strategy. The results also showed that the firm's export market performance has a positive impact on export financial performance. They concluded that the effect of national export-promotion programs on export-related resources and capabilities is stronger among smaller firms and, for some programs, among firms with less export experience.

A study by Freeman, Styles and Lawley (2012) explored how location - regional vs metropolitan impacts a small to medium sized enterprise (SME)'s access to firm resources and capabilities, and consequently its export performance. The study collected qualitative data from an expert panel of government trade advisors, as well as managers of SME exporters in Australian regional and metropolitan areas. The data were used to explore three propositions relating to the impact of location. The findings revealed that firms in metropolitan areas have an advantage over those in regional areas. However, contrary to expectations, the relatively lower level of competition in regional areas did not appear to have a negative impact on the export performance of firms located in these areas.

Masmoudi and Charfi (2013) did a study to explore the role of macro-economic determinants and to evaluate the effect of structural factors on the export competitiveness of the Tunisian economy, in a context of liberalization and crisis. The findings show that the effect of exchange rates and FDI on exports are significantly negative while the effect of gross fixed capital formation, which represents the effort of domestic investment, the liberalization policy and customs duty on imports are positive. Free trade agreement had significant and positive effect on exports. The variables related to structural competitiveness introduced in the model that is high-tech exports and public spending on research and development, have a positive effect on exports.

A study by Sung and Wen (2018) explored how political-economic forces could affect export performance in the renewable energy technologies market. They conducted panel framework analyses to verify the characteristics of panel data for 19 countries before establishing the panel estimator meant to test the effects of political-economic forces on export specialization. The results from the least squares dummy variable-corrected 
estimation indicate that the major factors promoting the export specialization of renewable energy technologies are, in order of decreasing importance, public pressure, market size, and government demand-pull policy. However, the traditional energy industry has no significant effect on export performance.

Depending on the context in which enterprises exist, the Macroenvironment can be contextualized in the following dimensions; physical, historical, economic, social-cultural and technological (Kibera, 1996). Studies including Jin, Peng and Song (2019) observed that macro-level environment (such as economic, political, social and technological forces) that firms face incidentally affect export performance from the external environment. Export performance is affected by internal and external barriers. Another study by Kormishkina et al., (2015) asserts that the macroenvironment conditions include political, monetary, socio-social, mechanical natural and legitimate powers,all were found to have significant effect on export growth. Quality appears to be affected by environmental conditions such as the degree of competitiveness, home nation governments ' legal and regulatory policies, and the existence of appropriate channels of distribution and communication among other factors. Walley (2008) observes that as the organization's external environment changes, its goals must respond to those changes, to reflect this changing environment. Organizations need to pay attention and match their operations to environmental circumstances in order to survive and operate competitively (Ansoff \& McDonnell, 1990).

Machuki and Aosa (2011) suggest that the environmental structure should be handled as two wide elements, the variables (inner and external) and the size. In terms of munificence, complexity and dynamism, the dimensional front of the setting as a building is defined. According to Mthanti (2012), because of the impeding threats and possibilities that emerge from the macro-environment of the company, the dangers are a function of the complexity and uncertainty connected with the setting, the company faces different kinds of hazards. Other scholars have also tried to establish the role and organizational structure of a firm, and its effect on company results, for example Dess et al. (2005). Gathungu et al. (2014) claimed that the capacity of a company to directly respond to the macro-environment is strongly dependent on the relationship between performance and other factors, including entrepreneurial orientation. Leonidou (2014) argues that the vibrant nature of today's environmental components presents a challenge in choosing which market platform to choose from. In the current study, the macro-environment is being interrogated to establish its influence on the relationship between firm resources and export performance of Small and Medium Manufacturing enterprises. 
As revealed in the literature, there is need to generally have clear link on how firm resources, macro environment and export performance with emphasis on the pragmatic development of a well-defined and theoretically reasonable framework based on the gathering of appropriate data, integrating independent and moderating variables with dependent export performance indicators. The specific macro-environment factors under review include,political,economic socio-cultural,technological,and legal. Recent studies indicate that roughly half of the export literature studies are now taking strategic and subjective export performance indicators which have also been confirmed. The conceptual view of variables is shown below.

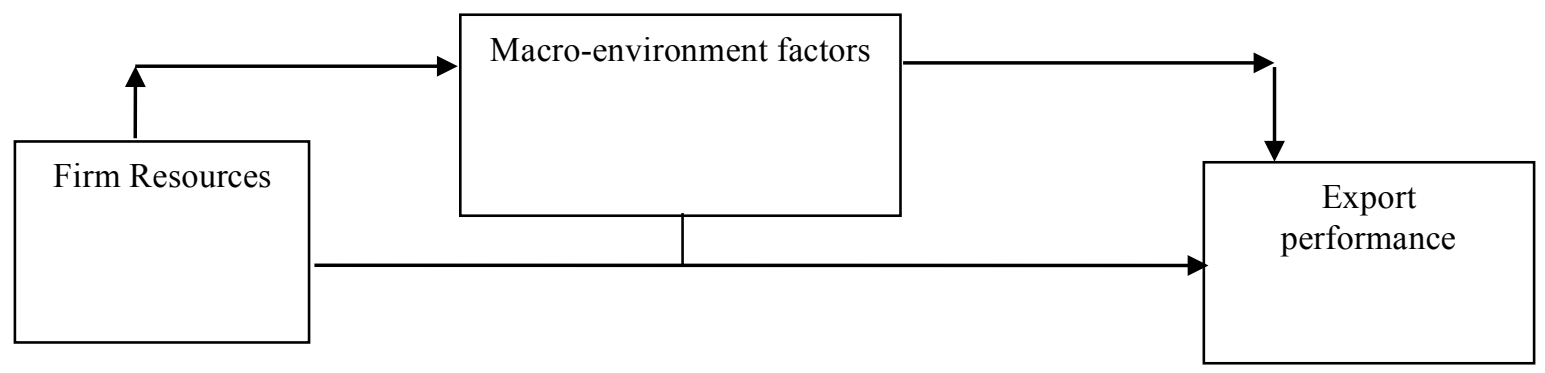

Figure 1: Conceptual Framework

\section{Methodology}

The research design adopted for the study was cross-sectional. The study investigated the influence of macro-environment on export performance of Small and Medium Manufacturing Enterprises. Crosssectional method enhances the credence and outcomes by offering timely findings on desired information. The advantage of this design is that they are carried out in natural settings and permits researchers to employ random probability samples. It also permits the researchers to make statistical inference to broader populations and permits them to generalize their findings to real life situations, thereby increasing the external validity of the study.

This study focused on Small and Medium scale Manufacturing Enterprises located within Nairobi City County that undertake exporting activity. The target population was divided into six main sub-sectors or categories of SMEs through stratified random sampling, all ,engaged in manufacturing within Nairobi City County. The sub-categories were,Pottery and Carvings,Textiles and Appareils,Plastics and Rubber,Chemical and Allied,Electricals,electronics and Engineering, and Food and Beverages.The target population consisted of 853 firms registered with Kenya Association of Manufacturers (KAM). Stratified random sampling was used by the 
researcher to acquire the sample per each sector. Using Krejcie and Morgan Table (1993) which serves as a ready reckoner for a population of less than 50,000 yielded the required sample size per sub-sector listed in the study.

The study applied a structured questionnaire in gathering primary and secondary data. This was complemented by online distribution using email and telephone follow-ups. One respondent per firm, specifically the CEO, or in his absence, a senior manager completed the questionnaire given their knowledge of the firm's history and operations. Secondary data pertaining to organizational characteristics and export performance were also obtained from financial outcomes and annual reports. Other sources of information were Kenya Association of Manufacturers (KAM), Export promotion Council (EPC) Export Promotion Zone Authority (EPZA), Ministry of Trade (MOT), Ministry of industrialization and SMEs website.

Data obtained from the field was entered in excel and subjected to cleaning by removing outliers and coding for further analysis. The coded data was analyzed using SPSS version 22.0 for both descriptive and inferential statistics. Quantitative data was summarized by measures of central tendency and spread in order to give descriptive analysis that represents the population. To obtain details about certain basic characteristics of the population, descriptive statistics were used to analyze individual study variables.

The study employed hierarchical regression model as suggested by Baron and Kenny (1986) to establish the moderating effect of macro environment on the relationship between firm resources and export performance of Small and Medium Scale Manufacturing Enterprises in Nairobi City County, Kenya. First a regression model (step 1) predicted export performance of Small and Medium Scale Manufacturing Enterprises from both the predictor in this case firm resources and the moderator in this case macro-environment. Step 2, regression involving firm resources, macro-environment and export performance of SMEs. Step 3, incorporating the interaction effect. Because both moderator and interaction term were significant, then moderation is occurred. The models tested in this hypothesis were as follows; $\mathrm{Y}=\mathrm{f}($ Firm Resources, Macro-Environment)

$\mathrm{Y}=\alpha+\beta_{1} \mathrm{X}+\varepsilon$

$\mathrm{Y}=\alpha+\beta_{1} \mathrm{X}+\beta_{2} \mathrm{~T}+\varepsilon$

$Y=\alpha+\beta_{1} X+\beta_{2} T+\beta_{3} X . T+\varepsilon$

Where $\alpha=$ constant (intercept), $\beta_{1}, \beta_{2}, \beta_{3}$ are the regression coefficients. $\mathrm{Y}=$ Export performance; $\mathrm{X}=$ Aggregated score for firm resources, $\mathrm{T}=$ macro-environment, $\mathrm{X} . \mathrm{T}=$ the interaction term of firm resources and macro-environment; $\varepsilon$-is an error term. In testing significance, model summary, Analysis of Variance (ANOVA) and 
coefficient of determination (R2) was used. Significance was tested at a 95 per cent confidence interval.

\section{Findings And Discussion}

Information and data based on responses from the firms that participated in the study are provided below in Table 1 .

Table 1: Distribution of Respondents by Age Bracket

\begin{tabular}{lll}
\hline Age bracket & Frequency & Percentage \\
\hline 18-34 years & 66 & 27.73 \\
35-39 years & 78 & 32.77 \\
40-44 years & 45 & 18.91 \\
45-50 years & 47 & 19.75 \\
51 years and above & 2 & 0.84 \\
\hline Total & $\mathbf{2 3 8}$ & $\mathbf{1 0 0}$ \\
\hline
\end{tabular}

Table 1 indicates that 32.8 percent of the respondents were in the 35 39 age category while 27.73 were in the $18-34$ age category. Only 2 respondents $(0.84 \%)$ were above 50 years of age. This observation showed that small and medium manufacturing enterprises were managed by mature adults. Considering the combined age brackets between 35 years and above compared to those who are between 18 and 34 years that is the youth, the former has approximately 72.3 percent as the latter maintains at 27.7 percent.

As observed from the previous sections, small and medium manufacturing sub sectors were considered as a major employer of workers of all age cadres. Similarly, older participants are deemed more experienced than young or new entrants to the manufacturing market (Chege \& Bula, 2015). This is regardless of the fact that there are young energetic youth and of reasonably higher education with an understanding of adoption and use of advanced manufacturing technology. Another school of thought with regard to age distribution, SMMEs with older managers are more likely to prefer lesser risk contractual arrangement whereas younger and energetic ones would prefer to engage in other alternatives which may not be industryfocused or related. At the same time, differences in contexts and cultural orientations could attribute to these contradicting observations.

\section{Distribution of SMMEs Participants by Level of Education}

The level of education attained by the sampled SMME respondents is important in that it plays a vital role in the adoption of new manufacturing technologies inclusive of marketing channels which may have a positive influence on export performance. The findings are indicated in Table 2. 
Table 2: Distribution of Respondents by Education Level

\begin{tabular}{lll}
\hline $\begin{array}{l}\text { Educational } \\
\text { qualification }\end{array}$ & \multicolumn{1}{c}{ Frequency } & Percent \\
\hline No formal education & 0 & 0 \\
Primary education level & 60 & 25.21 \\
Secondary education & 91 & 38.24 \\
level & 61 & 25.63 \\
Undergraduate level & 66 & 10.92 \\
Post graduate level & 26 & $\mathbf{1 0 0 \%}$ \\
\hline Total & $\mathbf{2 3 8}$ & \\
\hline
\end{tabular}

Results indicate that majority of the sampled SMME participants had a basic education whereby approximately 38.2 percent had studied up to secondary education level, with 25.6 percent and 25.2 percent had undergraduate level of education and the later had primary education level. Only 10.9 percent had postgraduate education level which included college and thus they also had a mix of skills from their college education. Further, there was no respondent under SMME who was identified as having no formal education and therefore could not read or write. However, the results of the study revealed that many of the participants in the study sampled were in the subsectors under manufacturing, were knowledgeable and with support could understand and utilize firm resources productively to enhance export performance.

According to Murphy and Myors (2004), education level determines the ability of the respondents to comprehend the survey questions and consequently use the findings for performance improvements. It would thus contribute towards individuals eyeing the SMME business to understand the different facets of the export performance as in the case of this study. On the other hand, Gibbs (2005) claimed that education enhances skills which lead to income and spurs invention and innovation resulting in rapid growth and development. It was therefore important to inquire about respondents' level of education. 


\section{Distribution by Position Held in the Firm}

The study further explored respondents via their respective positions in the firm. The findings are as shown in table 3.

Table 3: Level of Management of Respondents

\begin{tabular}{lll}
\hline Level of management & Frequency & Percentage (\%) \\
\hline Chief executive Officer & 65 & 24.53 \\
Production Manager & 90 & 33.96 \\
Personnel Manager & 110 & 41.51 \\
\hline Total & 265 & 100 \\
\hline
\end{tabular}

Study targeted to get feedback from senior management so as to make an informed conclusion. From the results, about $24.53 \%$ of the respondents were Chief Executive Officers, whereas Production Manager were $33.96 \%$. The majority of the respondents were Personnel Manages who were approximately $41.51 \%$.

\section{Age of Firm}

The study sought to determine the length of stay or existence of the sampled firms in the manufacturing sub-sectors identified under this study. This information was necessary as it was meant help to ascertain the extent their responses would be relied upon for valid conclusions based on experience. The results are outlined in Table 4.

Table 4: Age of Firm

\begin{tabular}{lcc}
\hline Age of firm & Frequency & Percentage \\
\hline Less than 3 years & 58 & 24.37 \\
3-6 years & 84 & 35.29 \\
7-10 years & 33 & 13.87 \\
Above 10 years & 63 & 26.47 \\
\hline Total & & $\mathbf{1 0 0 . 0}$ \\
\hline
\end{tabular}

From the findings, most of the firms, that is 35.3 percent had been in existence for a period of 3-6 years whereas approximately 26.5 percent had been in existence for more than ten years. About 24.4 percent and 13.9 percent had existed for less than three and 7-10 years respectively. The fact that almost 60 percent of businesses have been in existence in less than a span of 6 years, denoting new entrants in the manufacturing sub-sectors at a higher rate. From frequency distribution results, most of the sampled firms 
had an extensive experience in manufacturing business and therefore well versed with performance of the manufacturing sector and industry as a whole through their measurement indicators, a construct of interest to the present study. The experience of three and above years accounting for over 75.6 percent of the SMMEs was enough for the respondents in these sub sectors to offer valid responses based on a wider knowledge base of the general operations of a manufacturing sub sector.

\section{Ownership Status}

The study was also keen on understanding the ownership status of the SMMEs. The ownership was divided into three categories, these were; fully Kenyan owned, fully foreign owned, and joint ownership. The outcomes are presented in Table .5

Table 5: Distribution of Respondent in Terms of Ownership

\begin{tabular}{lll}
\hline Ownership Status & Frequency & Percentage \\
\hline Fully Kenyan Owned & 150 & 63.03 \\
Fully Foreign owned & 11 & 4.62 \\
Jointly owned & 77 & 32.35 \\
\hline Total & $\mathbf{2 3 8}$ & $\mathbf{1 0 0}$ \\
\hline
\end{tabular}

From the findings, the study found that approximately 63 percent of SMMEs were fully Kenyan owned followed by 32.4 percent which were jointly owned. The rest that is 4.6 percent were foreign owned. The findings are an indication that the government may have created an enabling environment for starting up new SMMEs. This syncs well with the fact that most business enterprises were registered less than six years ago, the same time the government began decentralization of the new system of governance, and adoption of modern technology to register a business.

\section{Descriptive Statistics on Firm Resources and Export Performance}

The study sought to establish the contribution firm resources variable towards export performance. The respondents indicated their opinions on the same by rating them on five-point Likert scale and the results are as presented in table 6 . 
Table 6: Firm Resources and Export Performance

\section{Firm Resources}

Raw materials influence export volumes

Raw materials influence growth of new export markets

Financial capital influences export volumes

Financial capital influences growth in new export markets

Human capital influences growth in export volumes

Human capital influences growth of revenue volumes

Human capital influences growth of revenue from exports

Firm processes influence growth of export volumes

Firm processes influence growth of new export markets

Firm processes influence growth of export volumes

Firm processes influence growth of new export markets

Firm processes influence growth of revenue from exports

\begin{tabular}{cc}
$\begin{array}{c}\text { Mean } \\
\text { Score }\end{array}$ & STD \\
\hline 3.685 & 1.022 \\
3.832 & 1.005 \\
3.866 & 1.109 \\
3.727 & 1.446 \\
3.815 & 1.173 \\
3.970 & 1.145 \\
3.962 & 1.096 \\
3.895 & 0.960 \\
4.088 & 0.975 \\
3.903 & 1.012 \\
4.058 & 1.160 \\
4.016 & 0.923 \\
\hline
\end{tabular}

Average Mean Score

The following items supported the fact that firm resources positively influenced export performance. They include; Firm processes influence growth of export volumes (3.903), Human capital influences growth of revenue from exports (3.962), Human capital influences growth of revenue from exports (3.97), Firm processes influence growth of revenue from exports (4.016), Firm processes influence growth of new export markets (4.058) and Firm processes influence growth of new export markets (4.088). This is because their mean scores were higher than the average mean score. On the other hand, the following statements indicated that firm resources had a negative influence on export performance. They include; Raw materials influence export volumes (3.685), Financial capital influences growth in new export markets (3.727), Human capital influences growth in export volumes (3.815), Raw materials influence growth of new export markets (3.832), Financial capital influences export volumes (3.866) and Firm processes influence growth of export volumes (3.895). 
Collectively, the study revealed that raw materials (3.759), and financial capital (3.797) negatively influenced export performance while human capital (3.916), and firm processes (3.992) had a positive influence on export performance.

\section{Descriptive Statistics on Macro-Environment and Export Performance}

The study sought to establish the moderating role of macroenvironment factors. Like firm resources variable, various macro-economic factors were directly linked to export performance. The respondents indicated their opinions on the same by rating them on five-point Likert scale and the results are as presented in table 7.

\section{Table 7: Macro -Environment and Export Performance}

\section{Macro Environment}

Mea STD

n

score

$3.496 \quad 1.17$

Political factors influence growth in export volumes

Political factors influence growth of new export markets

Political factors influence growth in revenue from exports

Economic factors influence growth of export volumes

Economic factors influence growth of new export markets

Economic factors influence growth in revenue from exports

Social cultural factors influence growth in export volumes

Social cultural factors influence growth of new export markets

Social cultural factors influence growth of revenue from exports

Technological factors influence growth in export volumes

Technological factors influence growth of new export markets

Technological factors influence growth in revenue from exports

Environmental factors influence growth in export volumes

\author{
6
}

$3.256 \quad 1.39$

8

$3.563 \quad 1.22$

7

$3.172 \quad 1.21$

9

$3.429 \quad 1.20$

2

$4.231 \quad 1.05$

6

$3.542 \quad 1.09$

7

3.8151 .09

1

$3.403 \quad 1.26$

8

$3.529 \quad 1.23$

8

1.33

4

$3.571 \quad 1.33$

7

$3.441 \quad 1.26$

7 
Environmental factors influence growth of new export $3.449 \quad 1.21$ markets

Environmental factors influence growth in revenue from exports

Legal factors influence growth of export volumes

$3.504 \quad 1.39$

Legal factors influence growth of new export markets

Legal factors influence growth in revenue from exports

Mean

From the descriptive analysis on macro environment construct, the average mean score for the construct was 3.573. The following items positively affected the construct; Legal factors influence growth of new export markets (3.592), Legal factors influence growth of export volumes (3.768), Social cultural factors influence growth of new export markets (3.815), Legal factors influence growth in revenue from exports (4.037) and Economic factors influence growth in revenue from exports (4.231). This was because their respective mean scores was more than the average mean score.

On the other hand, the following statements negatively affected the construct; Economic factors influence growth of export volumes (3.172), Political factors influence growth of new export markets (3.256), Social cultural factors influence growth of revenue from exports (3.403), Economic factors influence growth of new export markets (3.429), Environmental factors influence growth in export volumes (3.441), Environmental factors influence growth of new export markets (3.449), Political factors influence growth in export volumes (3.496), Environmental factors influence growth in revenue from exports (3.504), Technological factors influence growth of new export markets (3.508) and Technological factors influence growth in export volumes (3.529), social cultural factors influence growth in export volumes (3.542), Political factors influence growth in revenue from exports (3.563), Technological factors influence growth in revenue from exports (3.571), This is because their respective mean scores were less than the average mean score.

In summary, macro environment factors, including political factors (3.438), technological factors (3.536), and environmental factors (3.465) negatively influenced export performance while economic factors (3.611), social factors (3.587), and legal factors (3.799) had a positive influence on export performance. 


\section{Relationship between Firm Resource, Macro-environment and export performance}

To establish the hypothesized relationship, the study employed stepwise regression. The findings are as indicated in Table 8.

Table 8: Model Summary, Analysis of Variance and Coefficients Summary

\begin{tabular}{lllll}
\hline & & & \multicolumn{2}{l}{ Model Adjusted Std. Error of } \\
Model & R & R Square & R Square & $\begin{array}{l}\text { Estimate } \\
\text { the Etimate }\end{array}$ \\
\hline 1 & $.884^{\mathrm{a}}$ & .771 & .715 & .0687 \\
2 & $.997^{\mathrm{b}}$ & .992 & .913 & .0468 \\
3 & $.999^{\mathrm{a}}$ & .998 & .855 & .0359 \\
\hline
\end{tabular}

a. Predictors: (Constant), Firm Resources

b. Predictors: (Constant), Firm Resources, Macro-Environment

ANOVA $^{\text {a }}$

\begin{tabular}{|c|c|c|c|c|c|c|}
\hline \multirow{2}{*}{\multicolumn{2}{|c|}{ Model }} & \multicolumn{2}{|c|}{ Sum of } & \multirow{2}{*}{\multicolumn{2}{|c|}{ Mean Square F }} & \multirow{3}{*}{$\frac{\text { Sig. }}{.000^{b}}$} \\
\hline & & Squares & df & & & \\
\hline \multirow[t]{3}{*}{1} & Regression & 566.332 & 1 & 566.32 & 183.874 & \\
\hline & Residual & 812.02 & 264 & 3.08 & & \\
\hline & Total & 1378.352 & 265 & & & \\
\hline \multirow[t]{3}{*}{2} & Regression & 596.001 & 2 & 298.001 & 110.207 & $.000^{\mathrm{c}}$ \\
\hline & Residual & 711.101 & 263 & 2.704 & & \\
\hline & Total & 1307.102 & 265 & & & \\
\hline \multirow[t]{3}{*}{3} & Regression & 798.175 & 3 & 266.085 & 57.057 & $.000^{\mathrm{d}}$ \\
\hline & Residual & 1221.71 & 262 & 4.663 & & \\
\hline & Total & 2019.885 & 265 & & & \\
\hline
\end{tabular}

a. Dependent Variable: Export Performance

b. Predictors: (Constant), Firm Resources

a. Predictors: (Constant), Firm Resources, Macro-Environment

b. Predictors: (Constant), Firm Resources, Macro-Environment, Interaction Term

Coefficients $^{\mathrm{a}}$

$\begin{array}{ll}\begin{array}{l}\text { Unstandardized } \\ \text { Coefficients }\end{array} & \begin{array}{l}\text { Standardized } \\ \text { Coefficients }\end{array}\end{array}$

Std.

\begin{tabular}{|c|c|c|c|c|c|}
\hline Model & B & Error & Beta & $\mathbf{T}$ & Sig. \\
\hline (Constant) & .314 & .157 & & 2.000 & .046 \\
\hline Firm Resources & .865 & .064 & .689 & 13.560 & .000 \\
\hline
\end{tabular}




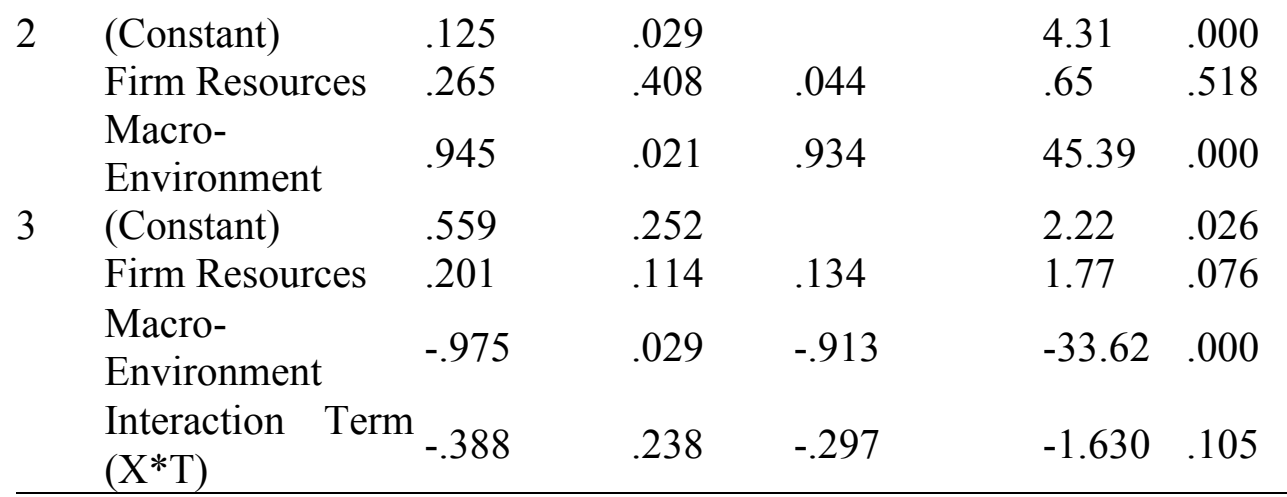

a. Dependent Variable: Export Performance

Table 8 shows results on the moderating effect of macro environment on the relationship between firm resources and export performance via step wise regression. In model one the result shows that the association between firm resources and export performance was moderate and significant $\left(\mathrm{R}=.884^{\mathrm{a},} \mathrm{R}^{2}=0.771, \mathrm{~F}=183.9\right.$, $\mathrm{P}$-value $\left.<0.05\right)$. In model two $\left(\mathrm{R}=.997^{\mathrm{a}}\right.$, $\mathrm{R}^{2}=.992, \mathrm{~F}=110.207, \mathrm{P}$-value $\left.<0.05\right)$ which was strong and the variables significantly explained dependent variable whereas in model three $\left(\mathrm{R}=.999^{\mathrm{a}}\right.$, $\mathrm{R}^{2}=0.998, \mathrm{~F}=57.057, \mathrm{P}$-value $<0.05$ ) which is strong implying independent, moderator and interaction term significantly explain the dependent variable at $5 \%$ level. This suggests presence of a moderating effect in model three after an interaction term is introduced.

Based on the coefficient as indicated in table 7 , the value of the interaction term $\left(X^{*} \mathrm{~T}\right)$ had a negative and non-significant influence $(\beta=$ $.388, \mathrm{t}=-1.630, \mathrm{P}>0.05)$. In addition, the respective effects of firm resources and macro-environment in the third model after introduction of an interaction term turned to be statistically insignificant $(p>0.05)$ thus confirming a presence of complete moderation effect of macro-environment. Based on this finding, the study rejected the null hypothesis that there is no significant moderating effect of macro environment on the relationship between firm resources and export performance of SMEs in manufacturing sector in Kenya. This finding was supported by the study result obtained by Sung and Wen (2018) which explored how political-economic forces could affect export performance in the renewable energy technologies market. The results indicated that the major factors promoting the export specialization of renewable energy technologies are, in order of decreasing importance, public pressure, market size, and government demand-pull policy..In a study by Ihesiene (2014) regarding policy and management challenges in Nigerian SMEs, it was revealed that other considerations include socio-political and economic policies governing SME operating environments. 
Studies including Jin, Peng and Song (2019) also found that macrolevel environment (such as economic, political, social and technological forces) that firms face incidentally affect export performance from the external environment. Another study by Kormishkina et al., (2015) the macro-environment conditions include political, monetary, socio-social, mechanical natural and legitimate powers were found to have significant effect on export growth. Gathungu et al. (2014) claimed that the capacity of a company to directly respond to the macro-environment is strongly dependent on the relationship between performance and other factors, including entrepreneurial orientation. Leonidou (2014) argues that the vibrant nature of today's environmental components presents a challenge in choosing which market platform to choose from. Also Machuki and Aosa (2011) suggest that the environmental structure should be handled as two wide elements, the variables (inner and external) and the size

\section{Conclusions}

Exporting is a critically important strategy for growth of SMEs. Literature has conspicuously indicated how research in this area has tended to ignore how firms especially in manufacturing sector can leverage resource-based capabilities to improve export performance. Considering the findings on firm characteristics, most of the firms had been in existence for a period of 3-6 years, whereas almost 60 percent of businesses have been in existence in less than a span of 6 years. This implies that most are new entrants in the manufacturing sub-sectors. Also, the study found that approximately 63 percent of SMMEs were fully Kenyan owned indicating that the government may have created an enabling environment for starting up new SMMEs.

From descriptive analysis of firm resources, it was established that raw materials and financial capital negatively influenced export performance while human capital, and firm processes had a positive influence on export performance. On the other hand, from the macro environment factors, it was concluded that factors including political factors, technological factors and environmental factors negatively influenced export performance while economic factors, social factors and legal factors had a positive influence on export performance.

From hypothesis testing, the study concluded that macro environment significantly moderates the relationship between firm resources and export performance of SMEs in manufacturing sector in Nairobi County, Kenya. Based on this conclusion, the study suggests the following; that for a firm to improve export performance, it has to align its export channel with its level of market orientation capabilities, contingent on the institutional distance between home and export markets. Also, exporting organizations must match 
firm processes and innovativeness levels to external environmental conditions and internal capabilities and structures. This is based on the finding that economic, social and legal macro environment factors had a positive influence on export performance.

\section{References:}

1. Alam, M. S., Atif, M., Chien-Chi, C., \& Soytaş, U. (2019). Does corporate R\&D investment affect firm environmental performance? Evidence from G-6 countries. Energy Economics, 78, 401-411.

2. Ansoff, H. I. \& Suvillan, A. P. (1993). Optimizing Profitability in Turbulent Environments: A Formula for Strategic Success. Long Range Planning, 26(5), 11-23.

3. Bertrand, O. (2011). What goes around, comes around: Effects of offshore outsourcing on the export performance of firms. Journal of International Business Studies, 42(2), 334-344.

4. Boso, N., Oghazi, P., Cadogan, J. W., \& Story, V. M. (2016). Entrepreneurial and market-oriented activities, financial capital, environment turbulence, and export performance in an emerging economy. Journal of Small Business Strategy, 26(1), 1-24.

5. Chen, J., Sousa, C. M., \& He, X. (2016). The determinants of export performance: a review of the literature 2006-2014. International Marketing Review.

6. França, A., \& Rua, O. L. (2018). Relationship between intangible resources, absorptive capacities and export performance. Tourism \& Management Studies, 14(1), 94-107.

7. Freeman, J., Styles, C., \& Lawley, M. (2012). Does firm location make a difference to the export performance of SMEs?. International Marketing Review.

8. Freixanet, J., \& Churakova, I. (2018). The impact of export promotion programs on firms' export competencies and performance in a transition economy: The case of Russian manufacturers. Journal of East-West Business, 24(4), 287-318.

9. Gathungu, J.M Aiko, D. M. \& Machuki, V.N. (2014). Entrepreneurial Orientation, Networking, External Environment, and Firm Performance: A Critical Literature Review. European Scientific Journal, vol.10, No.7.

10. Gaur, A. S., Ma, X., \& Ding, Z. (2018). Home country supportiveness/unfavorableness and outward foreign direct investment from China. Journal of International Business Studies, 49(3), 324-345. 
11. Grant, R. M. (1991). The Resource-Based Theory of Competitive Advantage: Implications for Strategy Formulation. California Management Review (spring), 114- 133. http://einspem.upm.edu.my/journal/fullpaper/vol9/1.\%20imon\%20\& $\% 20$ keya.pdf

12. Gregory, G. D., Ngo, L. V., \& Karavdic, M. (2019). Developing ecommerce marketing capabilities and efficiencies for enhanced performance in business-to-business export ventures. Industrial Marketing Management, 78, 146-157.

13. Guo, F., Zou, B., Zhang, X., Bo, Q., \& Li, K. (2020). Financial slack and firm performance of SMMEs in China: Moderating effects of government subsidies and market-supporting institutions. International Journal of Production Economics, 223, 107530.

14. Ihesiene, U.C., (2014) .A survey-based study of project management problems in small and medium scale enterprises (SMEs).European Scientific Journal September edition vol.10, No.25

15. Imran, M., Jian, Z., Urbański, M., \& Nair, S. L. S. (2018). Determinants of firm's export performance in China's automobile industry. Sustainability, 10(11), 4078.

16. Jin, P., Peng, C., \& Song, M. (2019). Macroeconomic uncertainty, high-level innovation, and urban green development performance in China. China Economic Review, 55, 1-18.

17. Kadochnikov, S. M., \& Fedyunina, A. A. (2017). The impact of financial and human resources on the export performance of Russian firms. Economic Systems, 41(1), 41-51.

18. Kibera, F.N. (1996). Introduction to Business: A Kenyan Perspective. Nairobi, Kenya Literature Bureau.

19. Kiveu, M. N., Namusonge, M., \& Muathe, S. (2019). Effect of innovation on firm competitiveness: the case of manufacturing SMEs in Nairobi County, Kenya. International Journal of Business Innovation and Research, 18(3), 307-327.

20. Kormishkina, L. A., Kormishkin, E. D., Semenova, N. N., \& Koloskov, D. A. (2015). Favorable Macro Environment: Formula of Investment Activity Growth under the Economic Paradigm Shifted. Mediterranean Journal of Social Sciences, 6(4), 163.

21. Krammer, S. M., Strange, R., \& Lashitew, A. (2018). The export performance of emerging economy firms: The influence of firm capabilities and institutional environments. International Business Review, 27(1), 218-230.

22. Krejcie, R.V. \& Morgan, D.W (1970). "Determining Sample Size for Research Activities." Educational and Psychological Measurement. 
23. Leonidou, L. C., Palihawadana, D., \& Theodosiou, M. (2011). National export-promotion programs as drivers of organizational resources and capabilities: effects on strategy, competitive advantage, and performance. Journal of International Marketing, 19(2), 1-29.

24. Leonidou, L.C, Palihawadana, D, \& Theodosiou, M. (2011). National Export Programs as Drivers of Organizational Resources and Capabilities: Effects on Strategy, Competitive Advantage, and Performance. Journal of International Marketing, 19(2), 1-29.

25. Li, J., Liu, B., \& Qian, G. (2019). The belt and road initiative, cultural friction and ethnicity: Their effects on the export performance of SMEs in China. Journal of World Business, 54(4), 350-359.

26. Liu, W., \& Atuahene-Gima, K. (2018). Enhancing product innovation performance in a dysfunctional competitive environment: The roles of competitive strategies and market-based assets. Industrial Marketing Management, 73, 7-20.

27. Machuki, V.N., \& Aosa, E. (2011). The Influence of the External Environment on the Performance of Publicly Quoted Companies in Kenya. Prime journals, 7, 205-218.

28. Masmoudi, M., \& Charfi, F. (2013). The macro-economic determinants of export competitiveness of the Tunisian economy in a context of liberalization and crisis. International Journal of Business and Management Invention, 2(7), 36-49.

29. Ngo, V. D., Janssen, F., Leonidou, L. C., \& Christodoulides, P. (2016). Domestic institutional attributes as drivers of export performance in an emerging and transition economy. Journal of Business Research, 69(8), 2911-2922.

30. Okpara, J. O. (2009). Strategic choices, export orientation and export performance of SMEs in Nigeria. Management Decision.

31. Porter, M.E. (1985). Competitive Advantage: Creating and Sustaining Superior Performance, Free Press: New York.

32. Raul, S., Isabel, A., \& Marta, F. O. (2016). Networks and export performance of agri-food firms: New evidence linking micro and macro determinants. Agricultural Economics, 62(10), 459-470.

33. Ribau, C. P., Moreira, A. C., \& Raposo, M. (2017). Export performance and the internationalisation of SMEs. International Journal of Entrepreneurship and Small Business, 30(2), 214-240.

34. Sadeghi, V. J., \& Biancone, P. P. (2018). How micro, small and medium-sized enterprises are driven outward the superior international trade performance? A multidimensional study on Italian food sector. Research in International Business and Finance, 45, 597-606. 
35. Sung, B., \& Wen, C. (2018). Causal Dynamic Relationships between Political-Economic Factors and Export Performance in the Renewable Energy Technologies Market. Energies, 11(4), 874.

36. UNIDO (2018). Industrial Development Report 2018. https://www.unido.org/resources-publications-flagship-publicationsindustrial-development-report-series/industrial-development-report2018

37. Xie, Z., \& Li, J. (2018). Exporting and innovating among emerging market firms: The moderating role of institutional development. Journal of International Business Studies, 49(2), 222245.

38. Yabs, J. (2010). Strategic Management Practices. Lelax Global (K): Nairobi. 